\title{
Hvað telst vera æskilegt gildi D-vítamíns í blóði?
}

\author{
Laufey Steingrímsdóttir \\ næringarfræðingur \\ laufst@landspitali.is
}

\section{Gunnar Sigurðsson}

sérfræðingur í efnaskipta- og innkirtlalækningum

Ofangreind spurning er algengt viðfangsefni lækna sem við teljum ástæðu til að ræða í ljósi nýlegra niðurstaðna úr Öldrunarrannsókn Hjartaverndar á tengslum mjaðmarbrota og 25-OHD-gilda í blóði. ${ }^{1}$

Styrkur 25-OHD í blóði tengist fjölda heilsupátta en áhrif D-vítamíns á beinheilsu eru pekktust og orsakasamhengið best staðfest enn sem komið er. Áhrif D-vítamíns á bein eru pó fyrst og fremst vegna virkni D-vítamínhormónsins 1,25-(OH) 2 D í meltingarvegi. Aukið frásog af kalki og fosfati úr fæðu fyrir tilstilli D-vítamínhormóns stuðlar að æskilegri péttni pessara jóna í blóði og útfellingu á kalsíumfosfati $\left(\mathrm{CaPO}_{4}\right)$ í beinvef, sem eykur styrk beinanna. D-vítamínhagur er oftast metinn með mælingum á styrk 25-OHD í blóði sem endurspeglar jafnt D-vítamín úr fæðu og nýmyndun pess í húð. Pykir 25-OHD í blóði betri mælikvarði á D-vítamínhag en mæling á hinu virka D-vítamínhormóni 1,25-(OH) $\mathrm{D}$ sem hefur skamman líftíma og stjórnast af öðrum páttum en styrk Dvítamíns.

Hvaða blóðgildi 25-OHD teljast æskileg fyrir beinheilsu hefur verið metið á ýmsa vegu, til dæmis með mælingum á beinpéttni og beintapi svo og með mælingum á kalkfrásogi frá görnum. Einnig hefur verið stuðst við athuganir á hvaða gildi af 25-OHD í blóði komi í veg fyrir sekúndera hækkun á kalkhormóni (PTH), sem endurspeglar nægilega péttni af jónuðu kalki í blóði. Við höfum áður notað pessa aðferð í stóru slembiúrtaki Íslendinga (n=1630) til að finna hvert gildi 25-OHD í blóði parf að vera til að kalkhormónið sé í jafnvægi. Við fundum að pessu jafnvægi var náð pegar 25-OHD í blóði hafði náð gildunum 45-50 nmól/L miðað við að kalkneyslan væri 800 mg á dag eða meira. ${ }^{2}$ Æskileg kalkneysla einstaklinga virtist pví verulega háð D-vítamínhag viðkomandi einstaklings.

Mikilvægasta mælikvarðann á D-vítamínhag fyrir beinin verður pó að telja hvaða gildi 25-OHD tryggi sem best eðlilegan beinstyrk og komi í veg fyrir beinbrot við lítinn áverka. Mjaðmarbrot er alvarlegasta beinbrotið sem verður við lítinn áverka og er pað algengast í eldra fólki eftir sjötugt. ${ }^{3}$ Par koma margir pættir við sögu, svo sem beinpéttni, vöðvastyrkur og jafnvægi, allt pættir sem hafa verið tengdir D-vítamínhag.

Nýlega birtum við ásamt samstarfsfólki niðurstöður úr Öldrunarrannsókn Hjartaverndar par sem við könnuðum brotatíðni og áhættu á mjaðmarbrotum eftir styrk 25-OHD í blóði við upphaf rannsóknartímabils (2002-2006). Rannsóknin tók til 5764 pátttakenda, bæði karla og kvenna, á aldrinum 66-96 ára. Pessum hópi var fylgt eftir í að meðaltali 5,4 ár og öll mjaðmarbrot (brot í lærleggs-

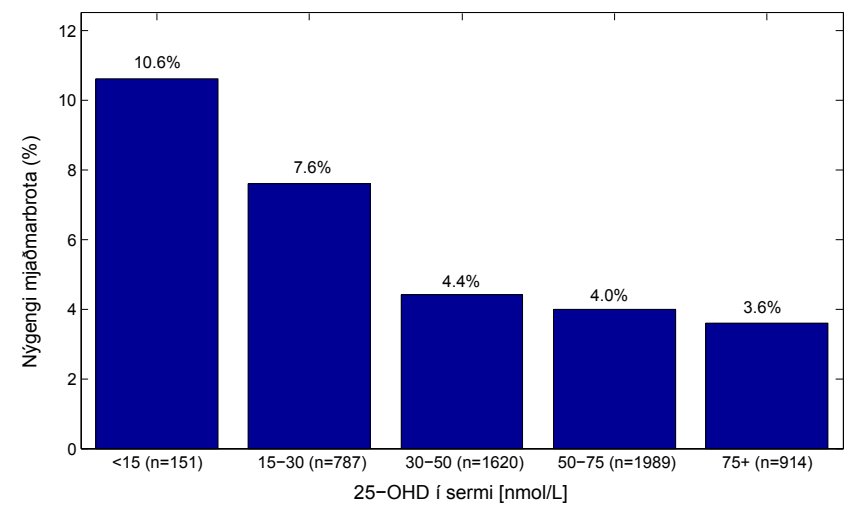

Mynd 1. Nýgengi mjaðmarbrota (\%) á 5,6 ára tímabili (SD1,5) meðal AGESpátttakenda $(N=5461)$ eftir grunngildum á 25-OHD í sermi. Oleiðrétt gildi. Birt með leyfi PLoS ONE.

hálsi og lærhnútum) vandlega metin og skráð í öllum hópnum. Alls urðu brotin 261 á tímabilinu og petta er pví ein stærsta framskyggna rannsóknin á pessu sviði sem birt hefur verið. ${ }^{1}$

Við lok rannsóknarinnar var fjöldi brota borinn saman við upphafleg gildi á 25-OHD í blóði. Mynd 1 sýnir pennan samanburð par sem hópnum er skipt eftir 25-OHD-gildum á lárétta ásnum. Tölfræðilegi viðmiðunarhópurinn var 50-75 nmól/L. Niðurstöðurnar sýna að peir sem voru með hærri gildi en 75 nmól/L og eins hópurinn með gildi á bilinu 30-50, voru ekki marktækt frábrugðnir viðmiðunarhópnum í brotatíðni. Hóparnir undir 30 nmól voru hins vegar með marktækt hærri brotatíðni, sem jókst verulega með lækkandi 25-OHD-gildum. Í heildina var áhættan meira en tvöföld á mjaðmarbroti ef viðkomandi einstaklingur, hvort heldur karl eða kona, var með 25-OHD-gildi undir 30 nmól/L. Beinpéttnin, sem mæld var á sama tíma og 25-OHD, var einnig marktækt lægri í hópnum með 25-OHD gildi undir 30 nmól/L en enginn marktækur munur var á öðrum hópum, hvorki 30-50 nmól hópnum, né 75 nmól og hærri, borið saman við pá sem höfðu 50-75 nmól/L. Reikna má út frá pessum tölum að 15\% allra mjaðmarbrotanna megi tengja lélegum D-vítamínhag, pað er 25-OHD <30 nmól/L (attributable risk). Ef petta er yfirfært til Íslands alls (um 300 mjaðmarbrot á ári) má væntanlega rekja um 40-50 mjaðmarbrot á ári til lélegs D-vítamínhags, undir 30 nmól/L af 25-OHD.

Institute of Medicine í Bandaríkjunum (starfrækt af National Academy of Sciences) birti árið 2011 viðmiðanir um lágmark æskilegra gilda af 25-OHD í blóði. Viðmiðanirnar byggðust á ítarlegri og kerfisbundinni samantekt og mati á fjölda rannsókna og par var komist að peirri niðurstöðu að lágmark æskilegra gilda væri 40-50 nmól/L. ${ }^{4}$ Pessar niðurstöður eru einnig í samræmi við ályktun í nýlegri kerfisbundinni samantekt norræns sérfræðihóps á æskilegum gildum á 25-OHD. ${ }^{5}$ Nýjar íslenskar ráđleggingar um D-vítamín frá Embætti landlæknis byggja einmitt á vinnu norræna sérfræðihópsins. ${ }^{6}$ Okkar niðurstöður úr rannsókn Hjartaverndar styrkja ályktun beggja pessara sérfræðihópa og benda ekki til að gildi yfir 45-50 nmól/L af 25-OHD skipti máli fyrir beinheilsu. 
Önnur samtök hafa túlkað birtar niðurstöður á annan veg og mælt með hærri viðmiðunarmörkum. Í mörgum tilvikum er par tekið mið af sjúklingahópum par sem D-vítamínbúskapur er annar en hjá heilbrigðu fólki.

Bæði ráðleggingar Institute of Medicine og pær norrænu byggja eingöngu á áhrifum D-vítamíns á bein, par sem önnur heilsuáhrif höfðu enn ekki verið nægilega staðfest að peirra mati. Hvort önnur viðmiðunargildi eigi við fyrir aðrar mögulegar verkanir Dvítamíns kemur væntanlega í ljós innan tíðar, en nú er unnið að fjölmörgum rannsóknum á pessu sviði.

Рað er vissulega áhyggjuefni að ekki skuli hafa tekist að tryggja D-vítamínhag aldraðra Íslendinga betur en raun ber vitni samkvæmt umræddri rannsókn Hjartaverndar.1 Allstór hópur fólks tekur ekkert D-vítamín aukalega, hvorki lýsi né D-vítamínbelgi, og sá hópur nær yfirleitt ekki æskilegum D-vítamínhag. Fyrri niðurstöður okkar benda til að 800 einingar $(20 \mu \mathrm{g})$ af D-vítamíni á dag nægi flestum öldruðum til að tryggja D-vítamín gildi í blóði yfir 40 nmól/L. ${ }^{2}$
Birt viðmiðunargildi fyrir 25-OHD hjá Landspítala eru 50-150 nmól/L. Í ljósi okkar niðurstaðna ætti pó fyrst og fremst að beina sjónum að peim sem hafa lægstu gildin (undir 30 nmól/L) frekar en að leitast við að toga gildin sem hæst.

\section{Heimildir}

1. Steingrimsdottir L, Halldorsson TI, Siggeirsdottir K, Cotch FM, Einarsdottir BO, Eiriksdottir $\mathrm{G}$, et al. Hip fractures and bone mineral density in the elderly-importance of serum 25-hydroxyvitamin D. PLoS ONE 2014; 9: e91122.

2. Steingrimsdottir L, Gunnarsson O, Indridason OS, Franzson L, Sigurdsson G. Relationship between serum parathyroid hormone levels, vitamin $\mathrm{D}$ sufficiency, and calcium intake. JAMA 2005; 294: 2336-41.

3. Siggeirsdottir K, Aspelund T, Jonsson BY, Mogensen B, Gudmundsson EF, Gudnason V, et al. Epidemiology of fractures in Iceland and secular trends in major osteoporotic fractures 1989-2008. Osteoporos Int 2014; 25: 211-9.

4. Ross AC, Manson JE, Abrams SA, Aloia JF, Brannon PM, Clinton SK, et al. The 2011 report on dietary reference intakes for calcium and vitamin D from the Institute of Medicine: what the clinicians need to know. J Clin Endocrinol Metab 2011; 96: 53-8.

5. Lamberg-Allardt C, Brustad M, Meyer HE, Steingrimsdottir L. Vitamin D - a systematic literature review for the $5^{\text {th }}$ edition of the Nordic Nutrition Recommendations. Food Nutr Res 2013; 57.

6. Embætti landlæknis. Upplýsingar um D-vítamín. landlaeknir.is/heilsa-og-lidan/naering/ greinar/grein/item21469/Upplysingar-um-D-vitamin - október 2014. 